\title{
Organo-mineral fertilizers and growth regulators of plants in organic farming
}

\author{
M. Vasilenko, doctor of Agricultural Sciences \\ Institute of agro-ecology and nature use NAAN
}

The purpose. To study influence of liquid complex fertilizers and growth regulators of plants on productivity and quality of crops in organic farming of Ukraine. Methods. Stationary and short-term field trials, conventional methods of researches, dispersion, correlation and variation analysis. Results Application of liquid complex fertilizers and growth regulators of plants increases productivity of crops and improves produce. Conclusions. It is expedient to spread considerably application of liquid complex fertilizers and growth regulators of plants.

Key words: productivity, quality, produce, complex fertilizers, growth regulators of plants.

Any society will not function properly if you do not have a developed agricultural sector and enough food for the population. Agrarian industry always took and takes the leading place in the solving of economic, environmental and social problems. After all, the State agricultural sector depends largely on welfare and living conditions of present and future generations of people. In Ukraine the major resource potential is the Earth. Therefore, in the history of Ukraine not only now, but also with the ancient agrarian question has always been relevant and challenging.

It is common knowledge that the main condition for obtaining high harvests of agricultural crops of proper quality is compliance with the principles of agriculture, especially the provision of optimal power plants, to achieve that without the use of fertilizers. Fertilizer is one of the earliest means of increase of productivity of agricultural crops.

In recent years, fertilizing and other means of hìmìzaciì has dramatically decreased, leading to a decrease in soil fertility and productivity of agricultural crops.

As a result of scarce provision of resources of agricultural production crop harvest is formed due to natural soil reserves of power supply elements.

Therefore, to change the traditional energy-consuming technology technologies have come fundamentally new technologies of farming, Sho based on the principles of balanced nature management, integrated management of land resources, concerted economic and environmental interests.

The application of organo-mineral fertilizers, plant growth regulators, certain increases productivity, improving agrochemical properties, especially away from the organo-mineral fertilizers, including the biological activity of the soil.

Organic-mineral fertilizers help binding harmful substances, heavy metals and residues of pesticides in an insoluble form that has a positive effect on the environment [3.4].

Organo-mineral fertilizers (OMD) does not contaminate the environment, this is a class 4 drugs toxicity. So now the special significance agroekologične substantiation of new fertilizers produced in Ukraine on the basis of domestic raw materials, as one of the ways of forming a safe, nizkovitratnogo energy and resursozberìgaûčogo element technology cultivation of agricultural crops [1.2].

Today, invented the technology elements that meet the above requirements. Research and informed use of elements of the technology with the use of new types of organic and mineral fertilizers, plant growth regulators, microbiological fertilizer and plant protection products allows you to not only improve the harvest, but also improve the quality and affect the timing of maturation and increase the resilience of agricultural plants to adverse environmental factors. When using the following technology decreases the 
norms of mineral fertilizers and pesticides, reduces the content of pollutants in crop production. Given the above chosen topic of scientific research is relevant.

Increase productivity of agricultural crops, the improvement of product quality largely depends on the level of providing soil nutrients.

To obtain high yields of agricultural plants (crops) to ensure all the necessary factors of life in an optimum ratio.

The main feature of the ground is its fertility. When soil fertility scientists understand it ability in varying degrees to meet the plants by earthly factors of life, the ability of the soil on the basis of its physical, chemical, physicochemical and biological properties serve to cultivated plants medium life, create conditions for industrial maintenance.

Therefore, the fertility of the soil — It is the ability to provide optimal conditions for obtaining the high performance of the respective cultures.

Population growth strongly requires the development of new methods, technologies increase the yield of major crops. This task at the present stage is impossible without broad application stimulants growth of plants.

Under STIlâtorami growth to realize synthetic andRodney organic chemicals, which is characterized by a significant biological activity and that in small amounts, in mikrodozah, causing changes in physiological and biochemical processes, growth, development and productivity of agricultural crops.

Stimulants growth is the Odit with important tools zbilšenNYA yields, improving their quality and storage.

It can be arguedthat in the next decade Vaultdistricts will have no less to produce than chemical fertilizers, plant protection. Without the use of STllâtorìv growth cannot be restarted to embody in the production of a series of intensive energy saving technologies of cultivation of most crops.

Modern technologies of obtaining high harvests, s.-h. crops beforeбačaût creation of optimal power plants tand trusted their protection from škìdnikìv, disease and weeds. Along with the selection-genetic and biotech methods one of the reserves increase yield and quality of crop production is the use of Stimulâtoriv growth of plants. In the last decade their sлand is widely used in the commercial production of various agricultural. cultures as important elements of ecologically safe resourcezberìgaûčih technologies [1, 2, 3, 4]. An important aspect of the action of growth regulators, along with increased yield and quality of grain, is the reinforcement of stability of plants to the unfavorable factors of environment: high and low temperatures, lack of moisture, fitotoksičnoï action pesticide damage diseases and pests, etc [3].

In their research, we studied one of the Gumisol of Vermicompost, organic and mineral fertilizersVitalist, OASIS, Dobrodij, stimulants-Emìstim, Endofit, Neofit, Ekostim, Hart, Noostim, Vegestim, Agrostim.

\section{Materials and methods.}

Characteristics of the products. Gumisol is brown visokogumusovana fluid that is produced from biohumus-product processing Californian worm pìdstilkovogo manure. The drug is odorless, has a high bactericidal and fungicides properties, it is not harmful for both humans and animals, insects, plants, and microorganisms. It is both a natural mikrodobrivom, also a powerful stimulator of growth and development of plants. The drug contains all of the components of Vermicompost in rumen condition: gumati, fulvokisloti, amino acids, vitamins, spores of soil microorganisms. He has a slabolužnu reaction. The process of obtaining the Gumisolu allows you to save all properties of the biohumus.

Vitalist is liquid, liquid organic-mineral fertilizer. It is intended for preseeding processing seeds and planting material and for foliar feeding crops.

In the composition Vitalistu is $3.4 \%$ and ammonium nitrogen $6.5 \%$ phosphorus, $7.9 \%$ potassium, $0.53 \%$ copper, $0.36 \%$ boron, $0.12 \%$ molybdenum. In addition, it is humic, fulvokisloti, biologically active substances with antistresovoû activity. 
The main advantage of Vitalistu is that macro-and microelements are physiologically-active organomineral form, allowing at low doses provide a substantial strengthening of the growth and development of crops. The latter is accompanied by increased productivity and quality of the crop.

Organo-mineral fertilizer OASIS is liquid light brown in color with a volume weight $1.46 \mathrm{tons} / \mathrm{m}$ Fertilizer intended for processing seeds and foliar feeding crops. The main advantage of Oasis lies in the fact that macro-and microelements are physiologically-active organo-mineral form, allowing at low doses provide a substantial strengthening of the growth and development of crops. This is accompanied by increased productivity and quality of the crop. Unlike traditional chemical fertilizers, "Oasis" fully digested at fertilization on seed and vegetative recharge while in pozakorenevomu.

The composition of the fertilizer are nitrogen, potassium and trace elements.

Dobrodij. A new composition, high-efficient, multi-functional fertilizer, which includes: humic and fulvokisloti, potassium, nitrogen, biogenic elements in halatnij form, as well as a plant growth regulator, which has fitogormonalnoû activity. Chemical composition: nitrogen nitrate-1.1\%, nitrogen amìdnij-21.1\%, potassium oxide-3.8\%, minerals: sulphur (8)-0.16 mg/kg magnesium (§)-1,8-2,2, boron (b)-0,02250,0250, copper (C) 0.125-0,150, zinc (2 I)-0.075-0,100, molybdenum (Mo)-0,00050-0,00075 mg/kg.

Field experiments were conducted on gray forest soils research fields of the Institute of agro-ecology and environmental sciences NAAN. CK soil layer had the slìduûču ecological-agrochemical characteristics: the content of humus was 1.18-1.23\% rNsol-4.8-5.0, gìdrolitična acidity-1.34 MEQ./OSI g soil Exchange basics-7.0-9.4 MEQ/100 g soil legkogìdrolìzovanogo nitrogen (by Kornfildu )-70-80 mg/kg, phosphorus-140-160, Exchange potassium 100-130 mg/kg. The size of the sowing area 30100 M'accounting, $2050 \mathrm{M}$ '. Povtornist the four with as alternating crops: wheat, soy, corn, wheat, potatoes, barley, sunflower, canola, 1/2 1/2. Used varieties of crops: wheat, spring-Early 93, corn-Hoverla, soyDove. Field experiments were carried out according to the methods b. a. Dospehova and DSTU 10.10.6.84 "field Experiments of fertilizers. Order them. Soil samples for analysis annually selected before the bookmark experiments and collecting $[9,10]$.

Laboratory analyses of soil and plant performed according to generally accepted methods, content of humus-by Tûrìnim (Ssu 4289-2004) legkogìdrolìzovanogo oxide-a Cornfield, mobile phosphorus and potassium Exchange by A.v.kirsanov (Ssu 4405-200), rNNSì-ìonometrično ( GOST 26483-85), gìdrolitična acidity due to Kappenom (STANDARD 26212-91), sum vvìbranih basics (GOST 27821-88), moving form of copper, manganese, cobalt and zinc-by Pejve-Rìnkisa, by means of atomic absorption method (GOST 10144-88), pine forest behind Berger and Trugora. Microbiological soil analysis carried out by conventional methods (Zvyagintsev, 1991). Accounting uraženostì crop diseases was carried out by a modified method of v.d. Peresipkìna and Pìdopličko (1977).

\section{The results of the research.}

Gumisol (extract from biohumus). 18-annual study, carried out on the black soili tipovOSU serednosuglinkovOSU, black soili opìdzolenOSU, CyrOSU lìsovOSU soiland, showed a high efficiency application Gumisolu. Sprayingwheat crop of drug Gumisol increased yield of corn on $0.50-0.74 \mathrm{t} / \mathrm{ha}$, or $19,0-29,4 \%$ (table 1).

Table 1 Impact Gumisolu on the yield and quality of crops in the field doslìdi (black soil of courseOyAAH, Ray, average for 1997-2005)

\begin{tabular}{|c|c|c|c|c|c|}
\hline \multirow[b]{2}{*}{ Options } & \multicolumn{2}{|c|}{ Spring wheat } & \multicolumn{3}{|l|}{ Corn } \\
\hline & $\begin{array}{l}\text { productivit } \\
\mathrm{y}, \mathrm{t} / \mathrm{ha}\end{array}$ & $\begin{array}{l}\text { the } \\
\text { contents of } \\
\text { the protein } \\
\text { in the } \\
\text { grain, } \%\end{array}$ & $\begin{array}{l}\text { Green } \\
\text { weight, t/it }\end{array}$ & Grain, t/ha & $\begin{array}{l}\text { protein } \\
\text { content in } \\
\text { the grain, } \%\end{array}$ \\
\hline Control (fertilizer) & 2,80 & 13,20 & 32,8 & 6,08 & 10,70 \\
\hline
\end{tabular}




\begin{tabular}{|l|l|l|l|l|l|}
\hline Spraying of crops, 6 I/HA & 0,53 & 13,78 & 7,1 & 1,12 & 11,75 \\
\hline Spraying of crops, 12 I/HA & 0,76 & 13,82 & 10,9 & 1,44 & 11,90 \\
\hline Treatment of seeds, 6 I/t & 0,39 & 13,47 & 8,9 & 0,87 & 11,65 \\
\hline $\begin{array}{l}\text { Treatment of seeds, 6 I/t + spraying } \\
\text { crops, } 6 \text { I/HA }\end{array}$ & 0,49 & 13,79 & - & - & - \\
\hline BURROWS & 0,26 & - & 24 & 0,68 & - \\
\hline
\end{tabular}

Note: yield of grain at the control without medication and pririst to control when applying Gumisolu

When applying the preparation on spring wheat Spring polìpšuvalas the quality of the grain, raised contents of bilkakolosu, length, number of grains in kolosku, mass. The application of the Gumisolu the seedingOh corn yield of grain increased the 2.16-2.43 m/HA. In this zbilšuvalupicture the length of cob, the amount of grain in steel, grain from the cob, the weight of 1000 grains. High expression of drug actionsee on other agricultural ...s cropsOhby: zlakovs, Bobovs, ovočevs, baštanns, fruit-âgìdns, grapesi and etc. Gumisol is compatible with all herbicides, insecticides and fungicides, which gives the possibility of make it along with inšimi products, without porušfull items the technological cycle, and does not require additional cost.

Unlike traditional chemical fertilizers, a significant share of that making contacts in the soil, organic and mineral fertilizers Vitalist, OASIS and Dobrodij fully grasp itюhappens when applied on seeds and vegetative recharge while in pozakorenevomu.

Vitalist. Foliar application Winter wheat crops organic-mineral fertilizer Vitalist increased productivity of grain at $0.40-0.59 \mathrm{t} / \mathrm{ha}$, the contents of bilka SPIC on $0.92-1.14 \%$ and gluten to $1.31-2.0 \%$. Vintageness of the grain of wheat of spring grade Collective-3 $y$ an average of four years of research increased in the $0.40-0.61 \mathrm{t} / \mathrm{ha}$, the contents of bilka - the $0.32-0.45 \%$ (tabl. 2). By obrobReplying to a message maize grain before sowing on yield was $0.86-1.56$ t/ha yield at 4.76 on controlling t/ha. Rmaking crops on vegetation provided increase in grain yield $1.17-1.77 \mathrm{t} / \mathrm{ha}(17.4-26.5 \%)$ and silage mass $-7.3-9.2 \mathrm{t} / \mathrm{ha}(5.5-19.2 \%)$, the contents of bilka $0.46-0.80 \%$ and protein increased by $0.32-0.88 \%$, respectively.

Table 2. Yield and quality of grain crops depending on the application of OMD Vitalist (CyrOy lisovOy soil testing field İAP, average 2005-2008 Gg.).

\begin{tabular}{|l|l|l|l|l|l|l|l|}
\hline \multirow{2}{*}{ Option } & \multicolumn{2}{|l|}{ Spring wheat, grain } & \multicolumn{2}{l|}{ Corn, grain } & \multicolumn{2}{l|}{ Soya, seeds } \\
\cline { 2 - 8 } & $\begin{array}{l}\text { productiv } \\
\text { ity, t/ha }\end{array}$ & $\begin{array}{l}\text { the } \\
\text { contents } \\
\text { of the } \\
\text { protein, \% }\end{array}$ & $\begin{array}{l}\text { producti } \\
\text { vity, t/ha }\end{array}$ & $\begin{array}{l}\text { the } \\
\text { contents } \\
\text { of the } \\
\text { protein, } \%\end{array}$ & $\begin{array}{l}\text { producti } \\
\text { vity, t/ha }\end{array}$ & $\begin{array}{l}\text { the } \\
\text { contents } \\
\text { of the } \\
\text { protein, } \%\end{array}$ & $\begin{array}{l}\text { fat } \\
\text { content, } \%\end{array}$ \\
\hline Control (BODA) & 3,50 & 10,82 & 6,71 & 6,87 & 2,10 & 18,08 & 20,16 \\
\hline Emistim, 10 ml/it & 0,20 & 10,93 & 0,45 & 6,98 & 0,30 & 19,18 & 20,72 \\
\hline Gumisol, 12 l/ga & 0,30 & 10,61 & 0,91 & 7,24 & 0,38 & 19,83 & 20,59 \\
\hline Vitalist, 20 I/ga & 0,40 & 11,14 & 1,17 & 7,33 & 0,31 & 19,56 & 20,40 \\
\hline Vitalist, 30 I/ga & 0,50 & 11,27 & 1,50 & 7,30 & 0,59 & 20,87 & 20,52 \\
\hline Vitalist, 40 I/ga & - & - & 1,77 & 7,74 & 0,80 & 20,05 & 20,62 \\
\hline Vitalist, 50 I/ga & 0,61 & 11,20 & 1,70 & 7,67 & 0,58 & 21,28 & 20,60 \\
\hline BURROWS & 0,19 & - & 0,18 & - & 0,20 & - & - \\
\hline
\end{tabular}

Note: Yield and the quality of grain control and gain relative to controls when using OMD Vitalist 
Obroblenyo Soybean Vitalist OMD before seeding increased productivity seeds a 0.33-0.73 t/ha (15.6$34.6 \%$ ) content bilka $-1.78-3.20 \%$ and fat content - on $0,24-0.40 \%$, spraying the crop yield of grain increased to $0.31-0.80 \mathrm{t} / \mathrm{ha}(14.8-38.1 \%)$. Yield of the control without fertilizers amounted to $2.10 \mathrm{t} / \mathrm{ha}$.

Dobrodij. Due to the significant amount of magnesium, contained in fertilizers, it the application of the provides an opportunity to improve not only the performance of many crops, but also quality products: increases accumulation of vitamins, carbohydrates, improved protein and fosfornij Exchange.

Hand sowing corn CyrOSU lisovOSU soili productivity of the masses increased on 10.6-16.0 t/ha (29.9-45.7\%)and, the black soili opìdzolenOSU - the 7.1-8.8 t/ha (14.7-18.2\%) yield of grain at 0.83$2.39 \mathrm{t} / \mathrm{ha}(8.3-23.9 \%)$. Processing of soybean Dobrodij fertilizer during the growing season provided increase productivity of grain on $0.50-0,86 \mathrm{t} / \mathrm{ha}(36.2-62.3 \%)$.

Introduction during vegetation of organo-mineral fertilizers Dobrodij increased grain yield of wheat of spring at $0.60-0.90 \mathrm{t} / \mathrm{ha}$ (table 3 ).

Table 3. Yield and quality of crops depending on the the application of the OMD Dobrodij on CyrOSU lisovOSU soili (see field İAP, the average for 2005-2008.)

\begin{tabular}{|c|c|c|c|c|c|c|c|}
\hline \multirow[b]{2}{*}{$\begin{array}{l}\text { A variant of the } \\
\text { experiment }\end{array}$} & \multicolumn{2}{|c|}{$\begin{array}{l}\text { ПShenicja Yar, } \\
\text { grain }\end{array}$} & \multicolumn{2}{|c|}{ Corn, grain } & \multicolumn{3}{|c|}{ Soya, seeds } \\
\hline & $\begin{array}{l}\quad \text { Vintag } \\
\text { e-Ness, } \\
\text { t/ha }\end{array}$ & $\begin{array}{l}\quad \text { the } \\
\text { share in } \\
\text { the- } \\
\text { growth, } \\
\%\end{array}$ & $\begin{array}{r}\text { produc } \\
\text { tivity, t/ha }\end{array}$ & $\begin{array}{l}\quad \text { the } \\
\text { share in } \\
\text { the- } \\
\text { growth, } \\
\%\end{array}$ & $\begin{array}{r}\text { produc } \\
\text { tivity, t/ha }\end{array}$ & $\begin{array}{l}\quad \text { the } \\
\text { share in } \\
\text { the } \\
\text { Growth, } \\
\%\end{array}$ & \begin{tabular}{l}
\multicolumn{1}{c}{ the } \\
contents \\
of the \\
protein \\
in the \\
grain, $\%$
\end{tabular} \\
\hline Control (water) & 2,78 & - & 6,30 & - & 1,38 & - & 21,6 \\
\hline Gumisol (Standard) & 3,14 & 12,9 & 7,92 & 9,8 & 1,65 & 19,6 & 21,1 \\
\hline Dobrodìj, 5 l/HA & 3,38 & 21,6 & 7,13 & 13,2 & 1,88 & 36,2 & 19,0 \\
\hline Dobrodij, $10 \mathrm{I} / \mathrm{HA}$ & 3,54 & 27,3 & 8,12 & 28,9 & 2,13 & 54,3 & 19,9 \\
\hline Dobrodìj, 20 I/HA & 3,68 & 32,4 & 8,69 & 37,9 & 2,24 & 62,3 & 20,2 \\
\hline BURROWS $_{\text {[i }}$ & 0,21 & & 0,36 & & 0,15 & & \\
\hline
\end{tabular}

Note: the yield of crops to control and increase control for the application of OHMD. Dobrodij

Norm costs new stimulators are 25-70 ml per 1 ton of seed or 25-50 ml for spraying 1 ra crops.

Over the past 15 years We LearnAli d.customevents 50 drugs and growth stimulant, new fertilizers, organo-mineral and microbial fertilizers. New drugs on the efficiency correspond to the best world preparations, they dominated by them, and by technological parameters have significant advantages and cost an order of magnitude cheaper. A sanitary-and-hygienic classification they belong to non-toxic substances.

Compatible application of herbicide of the stimulant growth reduces the negative effect of herbicide on the growth of microorganisms. According to the Gricaênko of $\mathrm{m}$. and its employees making herbicide together with stimulant growth positively affects the passage of basic physiological processes in plants of spring barley: in particular, the content of chlorophyll in the leaves and dry substances, increases the net productivity photosynthesis.

Research at the cellular and molecular levels of these and other authors, it was found that the increase of frost resistance of plants is associated with an increase in the cells under the influence of plant growth stimulant share associated content of water, carbohydrates and proteins, which support structure and functional organisation of the plants, raise the temperature switch citoplazmi from liquid to solid. 
Table 4. Yield and quality of crops depending on the use of drugs on gray forest soils (average for 2005-2010).

\begin{tabular}{|c|c|c|c|c|c|c|c|c|}
\hline \multirow[b]{2}{*}{ Variants of experiments } & \multicolumn{3}{|c|}{ Wheat spring } & \multicolumn{2}{|l|}{ Corn } & \multicolumn{3}{|l|}{ Soy } \\
\hline & $\begin{array}{l}\text { Harvest on } \\
\text { control and } \\
\text { gain } \\
\text { control, } \\
\text { T/HA }\end{array}$ & $\begin{array}{l}\text { Protein } \\
\text { conten } \\
t, \%\end{array}$ & $\begin{array}{l}\text { Content } \\
\mathrm{s} \quad \text { of } \\
\text { klejko- } \\
\text { fault,\% }\end{array}$ & $\begin{array}{l}\text { Harvest } \\
\text { on control } \\
\text { and gain } \\
\text { control, } \\
\text { T/HA }\end{array}$ & $\begin{array}{l}\text { Protein } \\
\text { conten } \\
t, \%\end{array}$ & $\begin{array}{l}\text { Harvest on } \\
\text { control and } \\
\text { gain control, } \\
\text { T/HA }\end{array}$ & $\begin{array}{l}\text { Protei } \\
\mathrm{n} \\
\text { conte } \\
\mathrm{nt}, \%\end{array}$ & $\begin{array}{l}\text { Fat } \\
\text { conte } \\
\text { nt, } \%\end{array}$ \\
\hline \multicolumn{9}{|l|}{ Ekostim } \\
\hline Control (water) & 3,02 & 12,60 & 20,4 & 5,27 & 7,80 & 2,30 & 22,15 & 18,36 \\
\hline Emistim, $10 \mathrm{ml} / \mathrm{it}$ & 0,22 & 13,18 & 20,4 & 0,39 & 8,13 & 0,40 & 22,86 & 19,16 \\
\hline Endofit, $10 \mathrm{ml} / \mathrm{it}$ & 0,33 & 13,35 & 22,4 & 1,52 & 8,63 & 0,42 & 23,23 & 20,30 \\
\hline Ekostim, $30 \mathrm{ml} /$ it & 0,65 & 13,20 & 25,6 & 1,64 & 9,00 & 0,98 & 22,96 & 19,98 \\
\hline Ekostim, $50 \mathrm{ml} / \mathrm{it}$ & 0,74 & 13,70 & 24,8 & 1,49 & 8,75 & 0,89 & 22,86 & 19,75 \\
\hline BURROWS & $0,13-0,15$ & & & 0,36 & & 0,15 & & \\
\hline \multicolumn{9}{|l|}{ Neophytus } \\
\hline Control (water) & 3,02 & 12,60 & & 6,05 & 7,80 & 1,75 & 22,10 & 18,40 \\
\hline Neofit, $50 \mathrm{ml} / \mathrm{HA}$ & 0,31 & 13,64 & & 1,45 & 8,44 & 0,37 & 23,00 & 20,40 \\
\hline BURROWS & 0,12 & & & 0,30 & & 0,14 & & \\
\hline \multicolumn{9}{|l|}{ Garth } \\
\hline Control (water) & 3,00 & 10,22 & & 8,42 & 6,88 & 1,87 & 18,70 & \\
\hline Garth, $50 \mathrm{ml} / \mathrm{it}$ & 0,43 & 10,81 & & 0,34 & 7,48 & 0,58 & 19,03 & \\
\hline Garth, $100 \mathrm{ml} / \mathrm{it}$ & 0,38 & 10,24 & & 0,57 & 7,32 & 0,35 & 20,50 & \\
\hline BURROWS & 0,31 & & & 0,76 & & 0,24 & & \\
\hline \multicolumn{9}{|l|}{ Noostim } \\
\hline Control (water) & 2,99 & 9,50 & 20,4 & 6,16 & 6,96 & 2,30 & 20,15 & 18,30 \\
\hline Noostim, $300 \mathrm{ml} / \mathrm{it}$ & 0,46 & 9,90 & 20,8 & 0,97 & 7,44 & 0,40 & 20,95 & 19,60 \\
\hline BURROWS & 0,22 & & & 0,26 & & 0,194 & & \\
\hline \multicolumn{9}{|l|}{ Vegestim } \\
\hline Control (water) & 3,47 & 9,40 & 23,60 & 6,25 & 7,75 & 1,90 & 20,30 & 20,07 \\
\hline Vegestim, $300 \mathrm{ml} / \mathrm{it}$ & 0,46 & 10,20 & 23,64 & 0,90 & 8,92 & 0,47 & 21,90 & 20,86 \\
\hline BURROWS & 0,13 & & & 0,25 & & 0,15 & & \\
\hline \multicolumn{9}{|l|}{ Agrostim } \\
\hline Control (water) & 2,45 & 10,58 & & 5,85 & 9,20 & 1,87 & 21,82 & \\
\hline Agrostim & 0,32 & 11,13 & & 1,99 & 9,36 & 0,47 & 23,40 & \\
\hline BURROWS & 0,12 & & & 0,16 & & 0,13 & & \\
\hline
\end{tabular}

In Western Europe up to $95 \%$ of crops grown with the use of plant growth stimulants. In recent years only on the area of up to 1 million. HA used plant growth stimulants. In terms of this year and in subsequent years under crops all cultures must make the necessary number of mineral, organic or organic-mineral fertilizers, growth stimulants and plant protection. Growth promoters need to handle the seeds before sowing and spray during the growing season.

Table 5. The research results of the drug "Ekostimu" (2008-2012., gray forest soils)

\begin{tabular}{|l|l|l|l|}
\hline Culture & $\begin{array}{l}\text { The increase of } \\
\text { crop T/HA }\end{array}$ & Optimum dose & $\begin{array}{l}\text { Quality } \\
\text { improvement, \% }\end{array}$ \\
\hline Seed treatment & $0,58-0,72$ & $40-50 \mathrm{ml} / \mathrm{t}$ & Protein $0.8-1.2 \%$ \\
\hline
\end{tabular}




\begin{tabular}{|l|l|l|l|}
\hline $\begin{array}{l}\text { Corn } \\
\text { Table } \\
\text { Grain }\end{array}$ & $\begin{array}{l}5,0-9,4 \\
0,90-1,19\end{array}$ & $50 \mathrm{ml} / \mathrm{t}$ & $\begin{array}{l}\text { Protein 1.0-2.1\% } \\
\text { Squirrel 0.65\% }\end{array}$ \\
\hline Soya & $0,82-0,94$ & $40-50 \mathrm{ml} / \mathrm{t}$ & $\begin{array}{l}\text { Squirrel 0.63-0.81\% } \\
\text { Fat 0,77-1.61\% }\end{array}$ \\
\hline Sunflower & $0,36-0,74$ & $50 \mathrm{ml} / \mathrm{t}$ & Fat 3,92-4,22 \\
\hline Spraying of crops & \multicolumn{3}{l|}{} \\
\hline Wheat & $0,60-0,82$ & $40-50 \mathrm{ml} / \mathrm{t}$ & Protein 0.8-1.2\% \\
\hline $\begin{array}{l}\text { Corn } \\
\text { Table } \\
\text { Grain }\end{array}$ & $6,2-8,2$ & $50 \mathrm{ml} / \mathrm{t}$ & $\begin{array}{l}\text { Protein } 1.0-2.1 \% \\
\text { Protein } 0.6-0.8 \%\end{array}$ \\
\hline Soya & $1,43-1,78$ & & FAT 1.60\% \\
\hline Sunflower & $0,89-1,08$ & $40-50 \mathrm{ml} / \mathrm{t}$ & Fat 3,91-4,22\% \\
\hline Rape & $0,30-0,45$ & $50 \mathrm{ml} / \mathrm{t}$ & FAT 1.10-1.27\% \\
\hline
\end{tabular}

Use of the drug increases the yield of crops, thus improves quality. In vegetables and fruits increases the content of proteins, sugars, and vitamins.

In this article, we harakterizuêmo only those drugs that we studied in recent years.

Table 6. Harvest of spring wheat in 2013 by r. depending on growth stimulants (typical chernozems, Lokhvytsia district, Poltava region)

\begin{tabular}{|c|c|c|c|c|c|c|}
\hline \multirow[b]{3}{*}{ Options } & \multirow{2}{*}{\multicolumn{3}{|c|}{ Diagram of the experiment }} & \multicolumn{3}{|c|}{ The results of the experiment } \\
\hline & & & & \multirow[b]{2}{*}{$\begin{array}{l}\text { Brožan̆nistb, } \\
\text { T/GA }\end{array}$} & \multicolumn{2}{|c|}{ Gain control } \\
\hline & $\begin{array}{l}\text { Seed } \\
\text { treatment, } \\
\mathrm{ml} / \mathrm{HA}\end{array}$ & $\begin{array}{l}\text { Pozakoreneva } \\
\text { treatment at } \\
\text { tillering stage, } \\
\mathrm{ml} / \mathrm{HA}\end{array}$ & $\begin{array}{l}\text { Pozakoreneva } \\
\text { processing in } \\
\text { phase } \\
\text { stooling, } \\
\mathrm{ml} / \mathrm{HA}\end{array}$ & & $\%$ & c/it \\
\hline Ekostim & 13 & 25 & 25 & 5,01 & 24,6 & 0,99 \\
\hline G-plant (гумат) & 128 & 500 & 500 & 4,81 & 19,6 & 0,79 \\
\hline Lìgnogumat (Rhodonite) & 102 & 300 & 300 & 4,79 & 19,0 & 0,77 \\
\hline Albite & 10 & 40 & 40 & 4,70 & 17,0 & 0,68 \\
\hline Kropmaks & 64 & 500 & 500 & 4,42 & 9,9 & 0,40 \\
\hline Control & & & & 4,02 & 0,0 & 0,00 \\
\hline Snr & & & & 0,075 & & \\
\hline
\end{tabular}

Application of plant growth stimulant Emistim in vegetation increased the harvest of wheat of spring at $0.22 \mathrm{t} / \mathrm{ha}$, protein content to $0.58 \%$ of the harvest of grain corn at 0.89 tons/HA, over at $0.33 \%$ and soybeans at $0.40 \mathrm{t} / \mathrm{ha}$, protein in soybeans at $0.7 \%$, fat at $1.8 \%$. 


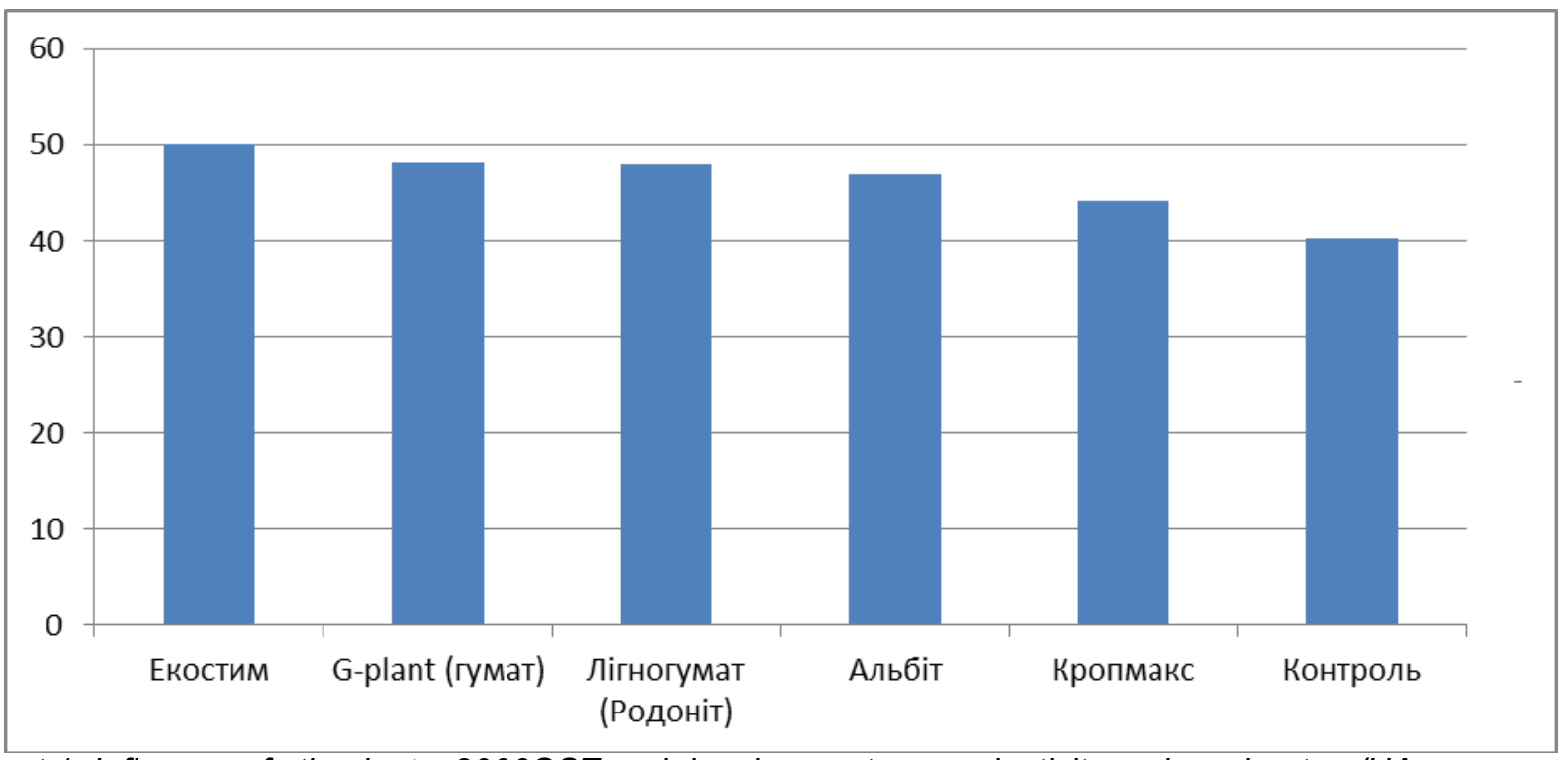

Chart 1. Influence of stimulants, 2006OST and development on productivity spring wheat, $\mathrm{m} / \mathrm{HA}$

Endofit at a dose of $10 \mathrm{ml} / \mathrm{HA}$ wheat grain yield increase gave spring $0.31 \mathrm{t} / \mathrm{ha}$, protein content grows to $0.75 \%$, harvest corn at $1.59 \mathrm{t} / \mathrm{ha}$ and protein content on $1.2 \%$, soybean at $0.42 \mathrm{t} / \mathrm{ha}$ protein in it to $1.07 \%$ and fat at $0.94 \%$.

In this doslìdì Ekostim at a dose of $30 \mathrm{ml} / \mathrm{HA}$ increased the harvest of wheat of spring at $0.63 \mathrm{t} / \mathrm{ha}$, and at a dose of $50 \mathrm{ml} / \mathrm{HA} 0.72 \mathrm{t} / \mathrm{ha}$, grain corn $1.64 \mathrm{t} / \mathrm{ha}$, protein content on $1.2 \%$, the harvest of soybeans increased to $0.98 \mathrm{t} / \mathrm{ha}$, protein content at $0.8 \%$ and fat on $1.62 \%$.

Application of Neofitu at a dose of $50 \mathrm{mg} / \mathrm{HA}$ increase harvest wheat at $0.31 \mathrm{t} / \mathrm{ha}$ and protein at $0.96 \%$, grain corn $0.95 \mathrm{t} / \mathrm{ha}$ and the content of protein at $0.64 \%$, harvest of soybeans to $0.37 \mathrm{t} / \mathrm{ha}$, protein content in it at $0.60 \%$, fat at $2.0 \%$.

Spraying of drug crops Garth dose 50-100 ml/HA grain harvest gains gave the spring wheat $0.53 \mathrm{t} / \mathrm{ha}$, protein $0.59 \%$, corn- $0.77 \mathrm{~kg} / \mathrm{ha}$, the protein in it at $0.60 \%$, soybean at $0.58 \mathrm{~kg} / \mathrm{ha}$, protein content at $0.60 \%$, fat on $1.80 \%$.

From Noostimu and Vegestimu in doses of $300 \mathrm{ml} / \mathrm{HA}$ wheat harvest of spring increased to $0.46 \mathrm{t} / \mathrm{ha}$, protein content $0.4-0.6 \%$ of grain corn at $0.90-0.97 \mathrm{t} / \mathrm{ha}$, protein to $0.48 \%$, soybean at $0.40-0.47$ tons/HA and fat $1.31 \%$. Similar results were obtained from Agrostimu at a dose of $25-50 \mathrm{ml} / \mathrm{HA}$.

In 2013, the typical chornozems of the Poltava oblast scientific employees of the company "Rice Maksymenko» conducted field research preparations and plant growth stimulant "Ekostim". The results of these studies are presented in table 6 and Figure 1. 
Table 7. Vintage the Green mass of corn ears depending on doses of endofitu in different soil fertilization (gray forest soils)

\begin{tabular}{|c|c|c|c|c|c|c|c|c|}
\hline \multirow[t]{3}{*}{$\# p / n$} & \multirow{3}{*}{$\begin{array}{l}\text { A dose of } \\
\text { fertilizer, kǵ/HA }\end{array}$} & \multirow{3}{*}{$\begin{array}{l}\text { Dose } \\
\text { endofitu, } \\
\mathrm{ml} / \text { it }\end{array}$} & \multicolumn{3}{|c|}{ Green table } & \multicolumn{3}{|l|}{ Forks } \\
\hline & & & \multirow[t]{2}{*}{$\begin{array}{l}\text { Harvest, } \\
\text { T/GA }\end{array}$} & \multicolumn{2}{|c|}{$\begin{array}{l}\text { The increase of the } \\
\text { harvest }\end{array}$} & \multirow[t]{2}{*}{$\begin{array}{l}\text { Harvest, } \\
\text { T/GA }\end{array}$} & \multicolumn{2}{|c|}{$\begin{array}{l}\text { The increase of the } \\
\text { harvest }\end{array}$} \\
\hline & & & & T/GA & $\%$ & & $\%$ & T/GA \\
\hline 1 & \multirow[t]{4}{*}{ Without fertilizers } & 0 & 18,5 & - & $\cdots$ & 4,00 & $-\ldots$ & - \\
\hline 2 & & 5 & 19,6 & 1,1 & 5,9 & 4,58 & 5,8 & 1,45 \\
\hline 3 & & 10 & 23,0 & 4,5 & 24,3 & 5,14 & 11,4 & 2,85 \\
\hline 4 & & 15 & 24,9 & 6,4 & 34,6 & 7,51 & 35,1 & 8,77 \\
\hline \multicolumn{9}{|c|}{$\mathrm{NIR}=1,56 \mathrm{~T} / \mathrm{HA}, \mathrm{p}=2,24 \%$} \\
\hline 5 & \multirow[t]{4}{*}{$\mathrm{P}_{90} \mathrm{~K}_{120}$} & 0 & 23,0 & - & - & 5,34 & - & - \\
\hline 6 & & 5 & 25,1 & 2,1 & 9,1 & 6,50 & 11,6 & 2,17 \\
\hline 7 & & 10 & 29,1 & 6,1 & 26,5 & 7,30 & 19,6 & 3,67 \\
\hline 8 & & 15 & 35,5 & 12,5 & 54,3 & 12,42 & 70,8 & 13,25 \\
\hline \multicolumn{9}{|c|}{$\mathrm{NIR}=2,22 \mathrm{~T} / \mathrm{HA}, \mathrm{p}=2.36 \%$} \\
\hline 9 & \multirow[t]{4}{*}{$\mathrm{N}_{120} \mathrm{P}_{90} \mathrm{~K}_{120}$} & 0 & 36,6 & - & - & 9,6 & - & - \\
\hline 10 & & 5 & 37,6 & 1,0 & 2,7 & 10,6 & 10,0 & 1,04 \\
\hline 11 & & 10 & 41,8 & 5,2 & 14,2 & 12,9 & 30,0 & 3,12 \\
\hline 12 & & 15 & 48,8 & 12,2 & 33,3 & 17,8 & 82,0 & 8,54 \\
\hline \multicolumn{9}{|c|}{ NIR = 3,22 T/HA, 2.41\% } \\
\hline 13 & \multirow{4}{*}{$\mathrm{P}_{90} \mathrm{~K}_{120}+\mathrm{N}_{120}$} & 0 & 36,0 & - & - & 10,9 & - & - \\
\hline 14 & & 5 & 38,3 & 2,3 & 6,4 & 11,5 & 6,0 & 0,55 \\
\hline 15 & & 10 & 41,7 & 5,7 & 15,8 & 12,1 & 12,0 & 1,1 \\
\hline 16 & & 15 & 49,0 & 13,0 & 36,1 & 18,0 & 71,0 & 6,51 \\
\hline
\end{tabular}

Ekostim - It is a water-alcohol solution of analogues of natural phytohormones (auxins cìtokìnìnìv, gibereliNIV) amino acids, carbohydrates, vitamins, fatty acids, trace elements and other biologically active substances, receiving of food metabolismy fungi endofitiv. Toxic and harmful substances in it are completely absent. The drug has the following basic properties: increases the germination and vigor of seeds and photosynthesis of plants, stimulate root formation, growth and development of plants, increases immunity to disease, increases the content of proteins, sugars and vitamins stimulates flowering. plants. Our studies on chornozems typical, opìdzolenih, gray opìdzolenih chornozems soils have shown high efficiency of application Ekostimu the crops are all agricultural ...s crops.

Stimulants the assetpoop the basic processes of life of plants- membrane processes, cell division, enzyme systems, photosynthesis, respiration and nutrition, promote increase of biological and economic efficiency of crop production.

The drug increases the vigor and similarity of seeds, contributes to the accelerated development of a strong root system (tillering node lies on the 1.5-2 cm deeper) and leaf surface, improves stamina of plants to disease and stress factors (high and low temperatures Drought (fitoksičnoï action of pesticides).

Use of the drug increases the yield of crops, while improving quality. The drug can be used both to process grain (seed) and the spraying of crops.

Our studies on chornozems typical, opìdzolenih, gray opìdzolenih chornozems soils have shown high efficiency of application «Ekostimu» the crops are all agricultural crops that we studied.

From the handling of seeds before sowing «Ekostimom» vintage kukurudzi increased by 5,0-9,4 T\ HA protein content on the $0.95-2.01 \%$, grains $0,90-1,19 \mathrm{~T} \backslash \mathrm{HA}$ protein content to $0.65 \%$; withErna soy $0,82-$ $0,94 \mathrm{t} \backslash \mathrm{HA}$ protein content on $0.63-0.81 \%$ fat $0,77-1.62 \%$, grain of sunflower on $0, \mathrm{Z7} \mathrm{t} \backslash \mathrm{HA}$. 
Application on vegetation sbilšsuvalo harvest of winter wheat $0,60-0,82 \mathrm{t} \backslash \mathrm{HA}$ protein content $0.4-1.4 \%$, gluten-free on the 2.0-5.2\%; mASA corn 6,2-8,2 t\ HA, seepthe corn to 1,78 $t \backslash$ GA, Soybean $0,80-1,08 \mathrm{t}$ $\mathrm{HA}$; sunflower seeds on $0,58-0,69 \mathrm{t} \backslash \mathrm{HA}$ fat content on the With,92-4.11\%; corn meal on $0,30-0,45 \mathrm{c} \backslash \mathrm{HA}$.

Stimpo. The newest drug polikomponentnij of biological origin. Part of the Stimpo includes the essential fatty acid S11-S28, carbohydrates (glucose, Galactose, g), 15 amino acids, trace elements-ions k, mn, $\mathrm{Mg}, \mathrm{Fe}, \mathrm{cu}$, analogues NAT.citokìnìnovoï 's auksinovoï and phytohormones of nature, biogenic elements, polyunsaturated fatty acids. The drug is intended for processing the seeds and obpriskution of crops of grain, leguminous, technical, vegetableexodus, fruit crops, edible fungi. Zastosovuêtsâ also decorative and forest trees, Kusah, for growing flowers and lawn grass.

Standards costs:

$25 \mathrm{ml}$ per 1 ton of seed;

$20 \mathrm{ml} 1$ ra crops.

Regoplant. Innovative bio-Stimulator plants from the field component drugs, the basis for which is based on sinergijnij effect of the interaction of the products of biotechnological kultivuvaATER mushrooms-mikromìcetiv of the root system of ginseng and Aveksektinì. The composition of the preparation is bìopreparat with anyou'reparazitarnoû action. Balanced composition Bioloo active compounds-analogues of phytohormones, amino acids,irThese acids, olìgosaharidìv and trace elements, as well as bìozahisnih compounds.

The drug is recommended for use for doposìssafe handling of seeds of cereals, leguminous, technical, plodovoâgìdnih, vegetable crops, potatoes, grapes, processing plants during the growing season, and also for obpriskytion of lawn grass, bushes. The drug has enhanced bìozahisnij effect in comparison with Stimpo.

Standards costs:

$250 \mathrm{ml}$ a ton of seeds;

$50 \mathrm{ml} 1$ ra crops.

Biolan. The drug is a product of biological origin. It is characterized by pìdvisennim content of analogues of phytohormones, amino acids, biogenic minerals and polyunsaturated fatty acids, responsible for the development of fitoaleksinìv.

Biolan is a drug of a wide range of actions infor processing seeds and spraying the plant Cafenew, leguminous, technical, vegetable, melonsthese crops, fruit and Berry crops, edible fungi. Is also used for ornamental and forest whererevah, bushes, flowers and herbs.

Standards costs:

$25 \mathrm{ml}$ per 1 ton of seed;

$20 \mathrm{ml} 1$ ra crops.

Treptolem. Effective composition of growth regulators of a natural on thewalking and synthetic analogueogìv phytohormones for processing Sunflower and canola. Transparent colourless aqueousalcohol solution.

Drug rekomendovathe key to use for peredposivnoï of seeds and spraying crops of sunflower and rape

\section{Standards costs:}

\section{$25 \mathrm{ml}$ per 1 ton of seed;}

\section{$20 \mathrm{ml} 1$ га crops.}

Radostim. analogues of phytohormones, amino acids, fatty acids, olìgosahariniv, content as forms mìkroelemention and bìozahisnih compounds.

Radostim used for preseeding rrobki seeds of cereals, leguminous, technical crops, as well as spraying of crops of these crops and lawn grass, introduction of large trees and bushes.

Standards costs:

$250 \mathrm{ml}$ per 1 ton of seed;

$50 \mathrm{ml} 1$ ra crops. 
Emistim C. Bio-stimulator of growth of a broad spectrum of action- biotechnological OLodCT mushrooms-epifitiv with ginseng root system. OLozorij bezbarvniй water-alcohol the solution, which contains a balanced complex of fitogoomonìv auksinovoï, citokìnìnovoï nature, amino acids, carbohydrates, fatty acids, mikroopementìv. The drug increases the vigor and similarity of seeds, plant resistance to disease (brown rust, root rot, etc.) and stress (viskoih and low temperatures, drought, fitotoksičnoïdiì of pesticides), reduces the intake of ions of heavy metals and radionuclides in products, increases the yield and improves the quality of plant products, EMìstim c zastosovuût on cereals, leguminous, technical, vegetables, melons and gourds, plodOvo-âgìdns cultures, decorative and forest trees, bushes, mushrooms and flowers.

Agrostimulìn. Complex of plant growth regulators of a natural origin and synthetic analogues of fitogoromonìv. Transparent colourless aqueous-alcohol solution. The drug increases the crop, improves quality of production, increases plant resistance to lodging, disease, stress factors. It is recommended for application on cereals, leguminous crops, perennial herbs.

Bìosil. The drug is an improved analog of the regulator of plant growth Agrostimulinu. It is a complex of bioregulators growth of natural origin, synthetic analogues of phytohormones and biogenic trace elements. Transparent colourless aqueous-alcohol solution. Recommended for processing and spraying of plants pšenvalue of winter, spring barley, soybeans, canola.

Obpriskuvannâ crops STIlâtorami in conjunction with herbicides and ìnsektofungìcidami allows you to reduce the rate of spending the past $25 \%$ and withdecrease their fitotoksičnu and mutagennu action [4].

Processing of crops Stimulatorami growth of plants Biolan and Bìosil reinforces the development of leaf surface and generative organs, increases the keelQty seeds in love yourself and their mass, increases the content of protein and gluten free, improves klasnist of grain [3].

Thus, the use of Stimulatorì growth by seed treatment with protrujnikom, as well as spraying of vegetuûčih plants in the phase bushing out as in pure form and in sumišcì with herbicides and a combination of these methods the polypšuvalo growth and development of plantsthat in General positively shaped the its generative organs and crop seeds.

An important consequence of the application of Stimulatorìv growth in our research was to increase the area of leaf surface plants and its fotosintetičnogo ontencialu.

Under any circumstances, in the wonderful setting of the bread grow need and it must grow with the least cost.

For sowing of winter crops under harvest of 2006 year more difficult weather conditions. Large areas of winter crops were sown in late and very late.

In the household «Zapadinske» Vasylkiv district of Kyiv region after harvesting corn in chornozems opìdzolenih in a field across from the Institute of mechanization by turning on the Krušinku was late was sown winter wheat Kiev 8 on the square 200 га. On the square 80 га the seeds before sowing was trimmed growth stimulant Endofit at a dose of $15 \mathrm{ml} / \mathrm{HA}$. Autumn in uhodì in winter the stairs of plants had a phase of šilcâ who are just coming out of the soil. Winter was cold and with little snow. Spring is cool and lingering. On the square 120 ra the plants died and crops he had. On the square 80 rawhere wheat seeds before sowing was trimmed growth promoters, the crops are not killed and when cleaning gave harvest another $45 \mathrm{t} / \mathrm{ha}$.

In the spring it is necessary to all crops, and primarily the weaker, urgent consequential "mineral, organic or organic-mineral fertilizers. Since the beginning of the growing season in the phase end of tillering-beginning of the exit tube crops need to handle growth promoters.

These are stimulants, like Ekostim, Endofit, Emìstim, Neofit, Hart, Noostim, Vegestim, Agrostim,

Bìosan, Bìosil and others, hood with Vermicompost - Gumisol and Vermìstin, organic and mineral fertilizers or liquid complex fertilizers Vitalist, OASIS Dobrodij, microbiological preparations and fertilizers.

The norms of the cost of the drug specified in the instructions, and akostimu, in the pre-seed treatment of cereals, legumes and other crops $25-40 \mathrm{ml}$ per 1 ton of seed, one hectare of crop, maize and sugar beet can be increased up to $40-50 \mathrm{ml}$. 
"Ekostim" is compatible with all herbicides, insecticides and fungicides, which allows to make it with other drugs without breaking the cycle and does not require additional expenses.

Handle seeds "Ekostimom" in advance at the same time with the protravlennâm, but you can and on the day of planting. Spraying of crops it is best to conduct the phase end of tillering-beginning of the exit tube. Corn, SoniawNick, beets (sugar, feed, table) tomatoes, cucumbers, cabbage, Eggplant sprayed in Phase 4-6 leaves, legumes and soybeans before butonìzaciêû. Potato process simultaneously with processing against the Colorado beetle in the solution of the drug add required amount of âdohìmikatìv.

You must seek dribnokapIHAZMATWow spraying fluid, ce more effectively impact on the plant.

Processing plants produce in the morning hours when the pores of the leaves open.

Benefits of stimulants (regulators) of plant growth.

1. Efficiency and effectiveness:

- technology applications do not require additional expenses, it is advisable to use stimulants in tank mixtures together with pesticides and nutrients;

- protection can be reduced to $15-20 \%$ of the norm;

- seed treatment before sowing the root system develops better subassembly tillering especially in winter crops on 1.0-1,5 cm located deeper, it's much better enables the perezimovuvati winterrape;

- guaranteed enhanced yield.

2. Impact on the quality of the products:

- under the influence of growth stimulants increased product quality, protein content, gluten, starch, sugar production;

- under the influence of the stimulant growth reduces crop production falling into ions of heavy metals and radionuclides;

- $\quad$ reduced contents of residual quantities of pesticides;

- $\quad$ the ability to use growth stimulants for growing of crop production for baby food;

- use the past for growing plants, bushes, fruit trees on the contaminated territories, including on private plots.

3. Reduce the risk of loss of the harvest:

- improved qualitative indexes of seeds in the processing of their protective and stimulating compositions;

- reduced incidence of plants and increases their resistance to stress due to the activation of the gene "sustainability";

- increases the resistance of plants as a result of the accumulation of large quantities of sugar and deeper site of tillering of winter crops;

- increased plant resistance to thermal shock;

- decrease the absorption of grain at the expense of the thickening wall stalks and lowering the standards of sowing seeds.

4. Impact on the ecology of the environment:

- $\quad$ activation of microflora of the soil (fosfatmobilizuûčih, fixing bacteria, symbiotic fungi, etc.);

- reduction of pesticidnoï loading on the ground as a result of decreasing standards of pesticide applications and decrease the final amount in the soil;

- $\quad$ reducing the impact on the bìotu soil;

- positively affect the increase in leaf surface and the content in the leaves of chlorophyll, increases utilization ANALYSIS.

Features of application of plant growth regulators

When using rìstregulûûcih drugs should take into account the fact that each of them created to stimulate and increase productivity certain saltskogospodarskih cultures in appropriate doses, timing and methods of application. 
Preparation of water working solutions. Growth regulators used in the form of water working solutions that prepare a day using them. The dose of their inclusion on the 1 a ton of seeds or 1 гектар crops are very small, so it is important that they are evenly distributed in the working solution for processing seeds or capacity for spraying of crops. For a more even distribution of the drug are preparing the first mother solution, where the required quantity of drug dissolved in $1 л$ water, carefully mixing. This solution is perelivaêmo in a bucket half filled with water, carefully stir and prove to 10 л. Capacity of the tank or tank sprayer half napovnâêmo with water, pour the required amount of liquor preparation together with pesticides, carefully stir and tolivaêmo the necessary amount of water, stirring all the time. Sharing with the promoters (the regulators) growth of pesticides at the pre-processing seeds and spraying crops during vegetation enhances efficiency of special substances, fungicides, insecticides and herbicides.

Requirements for processing seeds

The processing of seed grain kolosovih crops, sugar beets, corn, sunflower, a number of other crops carry on nasìnEBs, kukurudzo-gauge Mills, sortoselekcijnih stations and in individual farms. Specified plus requires special equipment and technology is made according to each culture, security According to sanitary norms and rules:

- seed treatment of ear crops use 10 л protective-stimulant composition per 1 ton of seed, but more qualitative processing-using $15 \pi$ the solution, which reduces the development of disease and increases economic efficiency (pribavka, improve product quality, reducing the costs of standards special substances to $1 \mathrm{t}$ the seeds);

- in farms processing small lots of seeds carried on the brezentì covered with a polyethylene film. In the process of spraying is necessary carefully stir the seeds for a uniform distribution of protectiveincentive substances on its surface.

Requirements to the spraying of crops. Sprayed crops of aqueous solutions growth regulators with sucker-Rod pumps sprayers. According to studies, significant impact on the efficiency of growth regulators have terms of spraying crops during the day. It is proven that most terms are the morning hours to the 10th hour and evening-after 17 hours.. Not allowed processing plants present equipment when wind speed more than $4 \mathrm{~m} / \mathrm{s}$. water Volume for field crops-200-300 I/HA.

\section{Conclusions}

1. Proven that the application of the new domestic organic-chemical, microbiological fertilizer and plant growth regulators complies with environmental requirements and provides ochery the natural environment, confirms the effectiveness of energy saving agrotehnologì̆, and promotes the creation of appropriate conditions for the growth and development of agricultural crops. Long-term agroekological research proven the feasibility and safety of a wide application of new plant growth regulators and fertilizers for growing wheat, corn, soybeans and other cropsthat does not pollute the natural environment, and received this products safe for spoživanand human health and animals.

2. Haukovacting reasonably and practically proven that the application of the study of new fertilizers (tukosumiš, ammophos-34), umìsol, OMD Vitalist, OASIS, Dobrodij, YYYY, Endofit Ekostim, Neofit, Vegestim, Noostim, Agrostim, microbiological fertilizer Azotovìt, Embìonìk increases the productivity and quality of products-pokra crop ŝê, not lowers fertility. The contents of the moving forms of nitrogen, phosphorus and potassium in the soil is not reduced with increasing productivity and even slightly increasing. Practically proven environmental and economic feasibility of applying new fertilizer and YYYY.

3. Seeozakoreneve application crops of wheat of spring Gumìsolom pìdvisisoftware productivity of grain at $18.0-27.1 \%$, Green mass of corn and grain at $52.0-59.8 \%$, Pre processed seeds provides increase urožaMark wheat $14.4 \%$ and green mass of corn $-8.9 \mathrm{t} / \mathrm{ha}$. Processing seeds with further pozakorenevim feed crops provided increase the productivity of grain on $18.6-26.7 \%$.

4. Significant increases in productivity of crops atStateAno for the application of OMD (Vitalist, Oasis, Dobrodij) SDožajnìst grain of wheat increased by $0.4-0.6 \mathrm{t} / \mathrm{ha}$, protein at $0,92-1,43 \%$ gluten at $1.30-$ 
2.00 , the yield of maize $-2.39-0,92 \mathrm{t} / \mathrm{ha}$, protein- $\mathrm{n}$. and $0.97-1.20 \%$ yield of soybean at $0.28-0,86 \mathrm{t} / \mathrm{ha}$, protein at $0.45-1.91 \%$ and fat - the $1.04-1.80 \%$.

\section{Reference}

1. Kalinin F. Biological actives Substances in crop production. -C. Naukova Dumka, 1984.0-316 C.

2. Nickell L. D. Regulatorb Plant growth. -M., Koloth, 1984. -91 C.

3. Ponomarenko CP. regulatorb Plant growth. -c. 2003. -312 C.

4. S.hrytsa€NCO with m., Ponomarenko CP., Karpenko VP' 'Leontûk and biologically active substances in agriculture. -CJSC "Nichlava", 2008. -345 c.

5. Dodsworth m.g. Agroekologične substantiation of application of new domestic fertilizer and growth regulators in agroekosistemah forest-steppe and Polissya/m. Dodsworth//Avtoref. dock. DIS. .. K2015-50

6. Volkogon V.v., Extruded Pp. The value of growth regulators in formation Active azotfiksuvalnih simbìozìv and the Association. Fiziologiâ and biohimiâ kulturnyh plants. -2005. Vol. 37 No.. 187197.

7. Tolstousov a., Ekobezpečnij I. Hilko: search strategy. -Knowledge of Ukraine.-200)-332 c.

8. Degodûk E. G., Sayko V.f. Kornìjčuk M. S. and others. Cultivation of ecologically pure products plant. -Vintage, 1992. -318 c.

9. The armor B.A. the technique of field experience. -M. Koloth, 1985. -351 C.

10. Handbook on the Organization of research work in the field of agricultural products. K., UkrNRKSGR-2010-136 s. 